\title{
HOW DEVIANT CAN YOU BE? \\ THE COMPLETE SOLUTION
}

\author{
AGNIESZKA GORONCY AND TOMASZ RYCHLIK
}

\begin{abstract}
We consider the problem of optimal deterministic lower and upper bounds on arbitrary linear combinations of order statistics centered about the sample mean in units generated by the sample central absolute moments of various orders. The signs of the evaluations depend merely on the coefficients of the linear combinations. Hitherto all the positive upper and negative lower bounds have been established as well as a few exceptional positive lower and negative upper ones. In the paper, we complete the solution by presenting all the positive lower bounds and negative upper bounds and respective samples attaining them. We also specify the general results by considering several important examples.
\end{abstract}

Mathematics subject classification (2000): 26D15, 62G30.

Key words and phrases: order statistic, $L$-statistic, optimal deterministic bound, projection, extreme point.

\section{REFERENCES}

[1] B. C. ARNOLD, Schwarz, regression and extreme deviance, Amer. Statist., 28, (1974), 22-23.

[2] B. C. ARNOLD, $p$-Norm bounds the expectation of the maximum of possibly dependent sample, J. Multivar. Anal., 17, (1985), 316-322.

[3] B. C. ARnOLD, N. BALAKRISHNAN, Relations, Bounds and Approximations for Order Statistics, Lecture Notes in Statistics, 53, Springer-Verlag, New York, (1989).

[4] B. C. ARNold, R. A. GRoENEVELD, Bounds for deviations between sample population statistics, Biometrika, 61, (1974), 387-389.

[5] B. C. ARnold, R. A. Groeneveld, Bounds on deviations of estimates arising in finite population regression models, Commun. Statist. — Theor. Meth., A7, (1978), 1173-1179.

[6] B. C. ARnold, R. A. Groeneveld, Bounds on expectations of linear systematic statistics based on dependent samples, Ann. Statist., 7, (1979), 220-223.

[7] B. C. ARNOLD, R. A. GROENEVELD, Maximal deviation between sample and population means in finite populations, J. Amer. Statist. Assoc., 76, (1981), 443-445.

[8] R. E. Barlow, D. J. Bartholomew, J. M. Bremner and H. D. BrunK, Statistical inference under order restrictions. The theory and application of isotonic regression, Wiley, London, (1972).

[9] P. R. BEESACK, On bounds for the range of ordered variates, Publ. of the Electrotechnical Faculty of Belgrade Univ., Math. \& Phys. Series, 428, (1973), 93-96.

[10] P. R. BEESACK, On bounds for the range of ordered variates II, Aequationes Math., 14, (1976), 293-301.

[11] A. V. BoYD, Bound for order statistics, Publ. of the Electrotechnical Faculty of Belgrade Univ., Math. \& Phys. Series, 365, (1971), 31-32.

[12] H. A. DAVID, General bounds and inequalities in order statistics, Commun. Statist. — Theor. Meth., 17, (1988), 2119-2134.

[13] H. A. DaVid, H. O. Hartley And E. S. Pearson, The distribution of the ratio, in a single normal sample, of range to standard deviation, Biometrika, 41, (1954), 482-493.

[14] M. DwASS, The extreme deviations inequality (Letter), Amer. Statist., 29, (1975), 108.

[15] S. Fahmy, F. Proschan, Bounds on differences of order statistics, Amer. Statist., 35, (1981), 46-47. 
[16] F. GonZacenco, E. MĂrgăRitescu, Best bounds for order statistics, Bull. Math. Soc. Sci. Math. R. S. Roumanie (N.S.), 31, (79) (1987), 303-311.

[17] F. GonZACEnCO, E. MĂRGăRITESCU AND V. G. VODĂ, Statistical consequences of some old and new algebraic inequalities, Rev. Roumaine Math. Pures Appl., 37, (1992), 877-886.

[18] R. A. GROENEVELD, Best bounds for order statistics and their expectations in range and mean units with applications, Commun. Statist. — Theor. Meth., 11, (1982), 1809-1815.

[19] D. M. Hawkins, On the bounds of the range of order statistics, J. Amer. Statist. Assoc., 66, (1971), 644-645.

[20] J. C. KOOP, On the derivation of expected value and variance of ratios without the use of intinite series expansions, Metrika, 19, (1972), 156-170.

[21] R. M. LoYNES, A note on Prescott's upper bounds for normed residuals, Biometrika, 66, (1979), 387-389.

[22] C. L. MAllows, D. RiCHTER, Inequalities of Chebyshev type involving conditional expectations, Ann. Math. Statist., 40, (1969), 1922-1932.

[23] E. MĂRgăRITESCU, Strict bounds for order statistics and Samuelson inequalities, Rev. Roumaine Math. Pures Appl., 32, (1987), 343-349.

[24] E. MĂRGăRITESCU, T. NICOLAE, Best linear bounds for order statistics in terms of the mean and the generalized range, Stud. Cerc. Mat., 42, (1990), 41-45.

[25] E. MĂRGĂRITESCU, V. G. VŎDA, An algebraic inequality and some applications in statistics, Stud. Cerc. Mat., 35, (1983), 376-387.

[26] D. S. Mitrinović, Analytic Inequalities, Springer-Verlag, Berlin, (1970).

[27] H. N. Nagaraja, Some finite sample results for the selection differential, Ann. Inst. Statist. Math., 33, (1981), 437-448.

[28] K. R. NAIR, The distribution of the extreme deviate from the sample mean and its studentized form, Biometrika, 35, (1948), 118-144.

[29] I. OlKIN, A matrix formulation on how deviant can an observation be, Amer. Statist., 46, (1992), 205-209.

[30] F. J. O'REILLY, On a criterion for extrapolation in normal regression, Ann. Statist., 3, (1975), $219-222$.

[31] F. J. O’REILly, The extreme deviations inequality (Letter), Amer. Statist., 30, (1976), 103.

[32] P. PRESCOTT, An upper bound for any linear function of normed residuals, Commun. Statist. - Theor. Meth., B6, (1977), 83-88.

[33] T. Robertson, F. T. Wright AND R. L. DyKstRA, Order Restricted Statistical Inference, Wiley, Chichester, (1988).

[34] R. T. RockAfElLER, Convex Analysis, Princeton Univ. Press, Princeton, (1970).

[35] T. RYCHLIK, Sharp inequalities for linear combinations of elements of monotone sequences, Bull. Polish Acad. Sci. Math., 40, (1992), 247-254.

[36] T. RYCHLIK, Sharp bounds on L-estimates and their expectations for dependent samples, Commun. Statist. — Theor. Meth., 22, (1993), 1053-1068.

[37] T. RYCHLIK, Bounds on expectations of L-estimates, in: Order Statistics: Theory \& Methods, Handbook of Statistics, Vol. 16, North-Holland, Amsterdam, (1998), pp. 105-145.

[38] P. A. SAmuelson, How deviant can you be?, J. Amer. Statist. Assoc., 63, (1968), 1522-1525.

[39] J. M. C. ScOTT, Appendix to paper by Pearson and Chandra Sekar, Biometrika, 28, (1936), 319-320.

[40] W. P. Sмith, Letter quoted in Editor's Note, Amer. Statist., 34, (1980), 251.

[41] W. R. THOMPSON, On a criterion for the rejection observations and the distribution of the ratio of deviation to sample standard deviation, Ann. Math. Statist., 6, (1935), 214-219.

[42] G. W. THOMSON, Bounds for the ratio of range to standard deviation, Biometrika, 42, (1955), $268-269$.

[43] H. Wolkowicz, G. P. H. Styan, Extensions of Samuelson's inequality, Amer. Statist., 33, (1979), 143-144. 